\title{
In vitro shoot induction and multiplication from nodal segments of adult Ginkgo biloba plants
}

\author{
Nilton César Mantovani ${ }^{1}$; Magali F Grando ${ }^{2}$; Aloisio Xavier ${ }^{3}$; Wagner C Otoni ${ }^{4}$ \\ ${ }^{1}$ UFSM-CESNORS, Depto. Eng Florestal, Lab. Biotecnol. e Melhoram. Genético Florestal, Linha Sete de Setembro s/n, BR 386, km \\ 40, 98400-000 Frederico Westphalen-RS; mantovani.nilton@gmail.com; ${ }^{2}$ UPF, Progr. Pós-Graduação em Agronomia, FAMV, Lab. \\ Biotecnol. Vegetal, Campus Universitário São José, 99010-970 Passo Fundo-RS; magali@upf.br; ${ }^{3}$ UFV, Depto. Eng. Florestal, Av. PH \\ Rolfs s/n, 36570-000 Viçosa-MG; xavier@ufv.br; ${ }^{4} U F V$, Depto. Biologia Vegetal; wotoni@ufv.br
}

\begin{abstract}
The in vitro performance of herbaceous and woody nodal segments from adult plants and the effect of hydrolyzed casein ( $\mathrm{HC}$ $500 \mathrm{mg} \mathrm{L}^{-1}$ ), kinetin (KIN; 6-furfurylaminopurine 0.46 and 4.65 $\mu \mathrm{M})$ and activated charcoal (AC $1.5 \mathrm{~g} \mathrm{~L}^{-1}$ ) were evaluated upon new shoots induction and development, and to establish a system of in vitro propagation from adult plants of Ginkgo biloba. Woody nodal segments did not produce axillary shoots and presented $100 \%$ of bacterial and fungal contamination in culture. However, nodal segments from herbaceous shoots were successfully disinfected and displayed high in vitro morphogenic capacity. The HC was essential for the axillary shoots induction and further multiplication, stimulating shoot formation in $85 \%$ of the cultured nodal segments and multiple shoots induction in $35 \%$ of them at establishment stage. During the multiplication stage, $66.6 \%$ of propagules formed new shoots and $33.3 \%$ of them formed multiple shoots when cultured with $\mathrm{HC}$. The KIN and AC inhibited the organogenic process in ginkgo. Two distinct patterns of sprouts development were observed in vitro, similar to what occurs in vivo: 1) short shoots with crowded internodes and expansion of only a few leaves and slow growth; 2) long shoots with separated nodes and marked apical growth. This is the first report of multiple shoots in vitro formation in nodal segments obtained from adult plants of Ginkgo biloba.
\end{abstract}

Keywords: hydrolyzed casein, activated charcoal, kinetin, multiple shoots, herbaceous and woody branches.

\section{RESUMO}

Indução e multiplicação in vitro de brotos de segmentos nodais de plantas adultas de Ginkgo biloba

Foi avaliado o comportamento de segmentos nodais lenhosos e herbáceos de plantas adultas e, os efeitos da caseína hidrolisada $(\mathrm{CH}$ $500 \mathrm{mg} \mathrm{L}^{-1}$ ), da cinetina (KIN; 6-furfurilaminopurina $0,46 \mu \mathrm{M} \mathrm{e} \mathrm{4,65}$ $\mu \mathrm{M})$ e do carvão ativado (CA 1,5 $\left.\mathrm{g} \mathrm{L}^{-1}\right)$ na indução e na posterior multiplicação de brotos, visando estabelecer um sistema de propagação in vitro a partir de plantas adultas de Ginkgo biloba. Segmentos nodais lenhosos não emitiram brotos axilares e apresentaram 100\% de contaminação fúngica e bacteriana durante o cultivo. Segmentos nodais de ramos herbáceos foram desinfestados com sucesso e apresentaram alta capacidade regenerativa in vitro. A CH foi essencial para a indução de brotos axilares e também para a posterior multiplicação destes, estimulando a formação de brotos em $85 \%$ dos segmentos nodais e múltiplos brotos em $35 \%$ destes na fase de estabelecimento das culturas. Na fase de multiplicação, $66,6 \%$ dos propágulos multiplicaram formando novos brotos e, 33,3\% formaram múltiplos brotos quando cultivados com $\mathrm{CH}$. A KIN e o CA provocaram efeitos inibitórios no processo organogênico de ginkgo. Foram observados dois padrões distintos de desenvolvimento de brotos in vitro, à semelhança do que ocorre in vivo: 1) brotos curtos, com segmentos internodais muito próximos, expansão de algumas folhas e de crescimento lento e; 2) brotos longos, com nós separados por segmentos internodais distintos e com maior crescimento apical que os anteriores. Este é o primeiro relato da formação in vitro de múltiplos brotos em segmentos nodais de plantas adultas de Ginkgo biloba.

Palavras-chave: caseína hidrolisada, carvão ativado, cinetina, múltiplos brotos, ramificações herbáceas e lenhosas.

(Recebido para publicação em 24 de fevereiro de 2012; aceito em 18 de março de 2013) (Received on February 24, 2012; accepted on March 18, 2013)

$G$ inkgo biloba is a Gymnosperm tree originated from China, the only living member from one of the oldest groups of seed plants, the Ginkgophytas (family Ginkgoaceae), dated the Permian period (Gifford \& Foster, 1989; Brenner et al., 2005). This species has a long history of use in medicine and as an ornamental plant in the landscape in different countries.

The main compounds synthesized by ginkgo are diterpene lactones, such as ginkgolides $\mathrm{A}, \mathrm{B}, \mathrm{C}, \mathrm{J}$ and $\mathrm{M}$, a sesquiterpene bilobalide and the flavonol glycosides quercetin, kaempferol and isorhamnetin (Van Beek, 2002). These compounds are found in the bark, roots and in greater quantity in the leaves of plants cultivated in the field (Van Beek, 2002) and also in in vitro regenerated plants and in cell cultures (Carrier et al., 1991; Camper et al., 1997; Balz et al., 1999; Gray et al., 2006; Kang et al., 2006; Sohier \& Courtois, 2007; Hao et al., 2009).

Ginkgo's extracts are widely used in medicine because the therapeutic properties, mainly related to the regulation of cerebral blood flow and protection against free radicals (Cheng et al., 2009). Studies also suggest that extracts of ginkgo may reduce the progression of dementia (Weinmann et al., 2010) and diabetes (Zhou et al., 2011).

The pharmaceutical companies 
have explored the medicinal properties of ginkgo through the production of standardized extracts, derived mainly from leaves. In the United States and Europe, billions of doses of these extracts were sold in two decades (Gray et al., 2006). However, there are difficulties to meet the demand for these compounds because only the United States and France grow this species in large scale for industrial purposes (Sohier \& Courtois, 2007).

The propagation of ginkgo from seeds is difficult because of the dioecism of the species, the long juvenile phase (Montez-López \& Rodríguez, 2001), the low germination rate, and the short period of seeds viability (Tommasi \& Scaramuzzi, 2004). Otherwise, the vegetative propagation through cuttings has low income and is extremely dependent on the juvenile nature of explants (Montez-López \& Rodríguez, 2001; Sexto, 2005), which also makes this technique difficult to be executed.

In vitro propagation of Ginkgo biloba from different morphogenic routes was reported exclusively from zygotic embryos and seedlings germinated in vitro (Laurain et al., 1996; Hao et al., 2000; Montes-López \& Rodríguez, 2001; Hu et al., 2002; Choi et al., 2004; Tommazi \& Scaramuzzi, 2004). However, these types of explants for in vitro culture are difficult to be obtained in countries where this species does not occur naturally and where the number of individuals is reduced, as is the case of Brazil.

There are only two reports in the literature on the cultivation of nodal segments and shoot apex from adult plants with the aim of in vitro propagation, but without success in the multiple shoots induction (MontesLópez \& Rodríguez, 2001; Tommazi \& Scaramuzzi, 2004). Thus, this study was carried out to evaluate the in vitro behavior of herbaceous and woody nodal segments obtained from adult plants of Ginkgo biloba, to compare the development pattern of shoots in vitro with the one observed in vivo, and to evaluate the effect of hydrolyzed casein, kinetin and activated charcoal in shoot induction and development, to establish an in vitro propagation system for G. biloba.

\section{MATERIAL AND METHODS}

This work was performed at the Laboratory of Plant Biotechnology from the University of Passo Fundo, Passo Fundo, Rio Grande do Sul state, Brazil, in partnership with the Federal University of Viçosa, Viçosa, Minas Gerais state, Brazil.

Adult plants of Ginkgo biloba, approximately 5 years old, on reproductive stage, generated from cuttings, were used as sources of explants. The plants were grown in a greenhouse (plastic containers with a capacity of 75.0 liters), under standardized nutrient and pesticide treatments, achieved by weekly sprays of solutions of interspersed systemic (Benomyl $1.0 \mathrm{~g} \mathrm{~L}^{-1}$ ) and contact fungicides (Captan $2.0 \mathrm{~g} \mathrm{~L}^{-1}$ ), and fertilizer biweekly with the Ouro Verde nutrient solution formulation $(3.0 \mathrm{~g}$ $\mathrm{L}^{-1}$ ), Takenaka SA Industry and Trade - Brazil, by water irrigation, directly in the substrate (5.0 L/container).

Two types of explants were tested: 1) nodal segments (20 mm length) with one axillary bud, excised from woody branches, older than 1 year, collected in winter (June); and 2) nodal segments (20 mm length) with one axillary bud, excised from herbaceous branches, 2 months old, collected in summer (January).

The methodology used for surface sterilization of the explants was the same used by Mantovani (2007), as described: immersion of nodal segments for $20 \mathrm{~min}$ in the fungicide solutions Benomyl (1.0 $\left.\mathrm{g} \mathrm{L}^{-1}\right)$ followed by Captan $\left(1.0 \mathrm{~g} \mathrm{~L}^{-1}\right)$, and in aseptic conditions, in a solution of ethanol (70\%) for 30 seconds followed by immersion in 2.5\% $(\mathrm{v} / \mathrm{v})$ solution of sodium hypochlorite $(\mathrm{pH}$ adjusted to 6.5$)$ plus Tween-20 (0.1\%) for 7 minutes.

The culture medium used was MS (Murashige \& Skoog, 1962) basal salts supplemented with $30.0 \mathrm{~g} \mathrm{~L}^{-1}$ sucrose, $100 \mathrm{mg} \mathrm{L}^{-1}$ myo-inositol and solidified with $7.0 \mathrm{~g} \mathrm{~L}^{-1}$ agar (Merck, Brazil). The $\mathrm{pH}$ was adjusted to $5.7 \pm 0.1$ with $\mathrm{NaOH}$ or $\mathrm{HCl}(0.1 \mathrm{~N})$ after the addition of growth regulators. The culture medium was distributed in aliquots of $10 \mathrm{~mL}$ in test tubes $(150 \times 25 \mathrm{~mm})$ and $50 \mathrm{~mL}$ in glass flasks $(240 \mathrm{~mL})$ and autoclaved for 15 minutes $\left(121^{\circ} \mathrm{C}\right)$.

Two stages of in vitro culture were evaluated: 1) establishment of nodal segments for growth induction of axillary shoots, and 2) the multiplication of shoots. In the establishment stage an experiment was carried out on complete randomized design, in a factorial scheme $2 \times 7$ (two explant types and seven combinations of media culture including

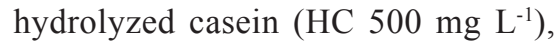
kinetin (KIN; 6-furfurylaminopurine $0.46 \mu \mathrm{M}\left(0.1 \mathrm{mg} \mathrm{L}^{-1}\right)$ and $4.65 \mu \mathrm{M}(1.0$

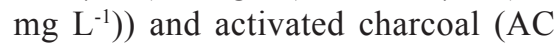
$1.5 \mathrm{~g} \mathrm{~L}^{-1}$ ) as follows: $\mathrm{MS}$; $\mathrm{MS}+\mathrm{HC}$; $\mathrm{MS}+\mathrm{HC}+\mathrm{KIN} 0,46 \mu \mathrm{M} ; \mathrm{MS}+\mathrm{HC}+\mathrm{KIN}$ 4,65 $\mu \mathrm{M} ; \mathrm{MS}+\mathrm{HC}+\mathrm{AC} ; \mathrm{MS}+\mathrm{HC}+\mathrm{KIN}$ $0,46 \mu \mathrm{M}+\mathrm{AC} ; \mathrm{MS}+\mathrm{HC}+\mathrm{KIN} 4,65$ $\mu \mathrm{M}+\mathrm{AC}$. The experiment consisted of 5 replicates (test tubes) by treatment with 4 tubes per replicate, and one explant per test tube.

The regenerated shoots obtained in the establishment stage, were transferred, after 30 days, to a fresh medium and used for the multiplication stage.

For the shoot multiplication stage, we also investigated the effect of hydrolyzed casein, kinetin, and activated charcoal added to the MS culture medium at the same concentrations and combinations used at establishment stage.

The experiment carried out in multiplication stage was conducted in a completely randomized design with 4 replicates (glass flasks) by treatment with 3 flasks per replicate and one shoot per flask.

The test tubes in establishment stage were kept in the dark in the first seven days after the explants inoculation. After, all the cultures were maintained under a $16 \mathrm{~h}$ photoperiod with $36 \mu \mathrm{mol}$ $\mathrm{m}^{-2} \mathrm{~s}^{-1}$ irradiance, provided by white fluorescent lamps (20 W, Osram, Brazil) and temperature of $25 \pm 2^{\circ} \mathrm{C}$.

After 30 days of the establishment of each experiment the frequency of explants with shoots and multiple shoots induction were assessed. The morphologic pattern of development 
of shoots produced in vitro during the establishment stage was compared with that observed in donor plants in vivo cultivated. We also observed the relationship between the patterns of development of new shoots in vitro with the position occupied (proximal or distal) by the nodal segment in the original branch in donor plants.

The statistical analyses were performed with the SAEG (Sistema de Análises Estatísticas e Genéticas, Universidade Federal de Viçosa, Brazil, Ribeiro Júnior, 2001) software. Analysis of variance was applied and means were compared using Tukey's test $(p=0.05)$.

\section{RESULTS AND DISCUSSION}

Establishment of nodal segments for growth induction of axillary shoots - The maintenance of ginkgo plants sources of explants in the greenhouse under nutrient and pesticide management promoted the appropriate conditions for the shoots formation and obtainment of the explants. These plants presented short and long shoots formed during the season of growth (spring-summer), the bilobaded leaves, typical of the species (Figure 1A), and the microsporangiate strobili (Figure 1B) showing the adult stage of the plants.

The season of the year and the age of the branches from which the explants were excised influenced the in vitro establishment of G. biloba. Nodal segments of woody branches, older than one year, excised in June (winter in Brazil), when the plants do not contain leaves, presented $100 \%$ of bacterial and fungal contamination, even after the procedure of surface disinfection. In this explant (Figure 1C), the periderm was fibrous, showing the woven bracts protecting the shoot buds in this period of dormancy. The presence of periderm, common in woody branches, favors the accumulation of contaminant microorganisms, making difficult the effective penetration and action of agents used in the surface sterilization process (Mantovani, 2007).

There was no in vitro induction of shoots from axillary buds of woody nodal segments. Similar behavior in relation to contamination and lack of regeneration in this type of explant was observed by Sexto (2005).

Nodal segments from herbaceous branches, with 2 months of age (Figure 1D), excised in January (summer in Brazil), period of active growth of the plant, were disinfected and successfully established in vitro. These explants have smooth epidermis and axillary buds in early stage of growth, a condition that reduces the presence of contaminating agents, allowing better disinfection (Sexto 2005; Mantovani, 2007).

The regenerative potential of herbaceous explants at the establishment stage was influenced by the presence of $\mathrm{HC}, \mathrm{KIN}$ and $\mathrm{AC}$ in the culture

Table 1. Effect of hydrolyzed casein (HC) $500 \mathrm{mg} \mathrm{L}^{-1}$, kinetin (KIN) 0.46 and $4.65 \mu \mathrm{M}$ and activated charcoal (AC) $1.5 \mathrm{~g} \mathrm{~L}^{-1}$ in MS medium, on the percentage of development of axillary shoots and multiple shoots from herbaceous nodal segments of Ginkgo biloba adult plants, after 30 days of cultivation in vitro during the establishment stage (efeito da caseína hidrolisada (CH) $500 \mathrm{mg} \mathrm{L}^{-1}$, da cinetina (KIN) 0,46 e 4,65 $\mu \mathrm{M}$ e do carvão ativado (CA) 1,5 $\mathrm{g} \mathrm{L}^{-1}$ no meio MS, sobre a porcentagem de segmentos nodais herbáceos de plantas adultas de Ginkgo biloba com formação de brotos axilares e múltiplos brotos, aos 30 dias de cultivo in vitro durante a fase de estabelecimento). Passo Fundo, UPF, 2009.

\begin{tabular}{lcccccccc}
\hline \multirow{2}{*}{ Treatments } & \multicolumn{6}{c}{ Nodal segments (\%) } \\
\cline { 2 - 7 } & \multicolumn{2}{c}{$\begin{array}{c}\text { with shoots } \\
\text { induction** }\end{array}$} & $\begin{array}{c}\text { with multiple shoots } \\
\text { induction** }\end{array}$ \\
\hline MS (control) & 0.0 & \pm & 0.0 & $\mathrm{~d}$ & 0.0 & \pm 0.0 & $\mathrm{~b}$ \\
$\mathrm{MS}+\mathrm{HC}$ & 85.0 & \pm 13.6 & $\mathrm{a}$ & 35.0 & \pm 13.6 & $\mathrm{a}$ \\
$\mathrm{MS}+\mathrm{HC}+\mathrm{KIN} 0.46 \mu \mathrm{M}$ & 50.0 & \pm 17.6 & $\mathrm{~b}$ & 10.0 & \pm 13.6 & $\mathrm{~b}$ \\
$\mathrm{MS}+\mathrm{HC}+\mathrm{KIN} 4.65 \mu \mathrm{M}$ & 45.0 & \pm 20.9 & $\mathrm{bc}$ & 5.0 & \pm 11.1 & $\mathrm{~b}$ \\
$\mathrm{MS}+\mathrm{HC}+\mathrm{AC}$ & 0.0 & \pm 0.0 & $\mathrm{~d}$ & 0.0 & \pm 0.0 & $\mathrm{~b}$ \\
$\mathrm{MS}+\mathrm{HC}+\mathrm{KIN} 0.46 \mu \mathrm{M}+\mathrm{AC}$ & 20.0 & \pm 11.1 & $\mathrm{~cd}$ & 0.0 & \pm 0.0 & $\mathrm{~b}$ \\
$\mathrm{MS}+\mathrm{HC}+\mathrm{KIN} 4.65 \mu \mathrm{M}+\mathrm{AC}$ & 25.0 & \pm 17.6 & $\mathrm{bcd}$ & 5.0 & \pm 11.1 & $\mathrm{~b}$ \\
\hline
\end{tabular}

**Means \pm s.e. (standard error) of 5 replicates with 4 explants; means followed by the same letter within the same column are not statistically significant by Tukey test $(\mathrm{p} \leq 0.05)$ [**médias \pm desvio padrão de 5 repetições com 4 explantes; médias seguidas da mesma letra, na coluna, não diferem pelo teste de Tukey $(\mathrm{p} \leq 0,05)]$.

Table 2. Effect of hydrolyzed casein (HC) $500 \mathrm{mg} \mathrm{L}^{-1}$, kinetin (KIN) 0.46 and $4.65 \mu \mathrm{M}$, and activated charcoal (AC) $1.5 \mathrm{~g} \mathrm{~L}^{-1}$ in MS medium on the percentage of propagules of Ginkgo biloba with shoots formation and multiple shoots, after 30 days of cultivation in vitro during the multiplication stage (efeito da caseína hidrolisada $(\mathrm{CH}) 500 \mathrm{mg} \mathrm{L}^{-1}$, da cinetina (KIN) 0,46 e 4,65 $\mu \mathrm{M}$, e do carvão ativado (CA) $1,5 \mathrm{~g} \mathrm{~L}^{-1}$ no meio $\mathrm{MS}$, sobre a porcentagem de propágulos de Ginkgo biloba com formação de novos brotos e múltiplos brotos, aos 30 dias de cultivo in vitro na fase de multiplicação). Passo Fundo, UPF, 2009.

\begin{tabular}{lcccccc}
\hline \multirow{2}{*}{ Treatments } & \multicolumn{5}{c}{ Propagules (\%)* } \\
\cline { 2 - 7 } & $\begin{array}{c}\text { with shoots } \\
\text { formation ** }\end{array}$ & $\begin{array}{c}\text { with multiple shoots } \\
\text { formation } * *\end{array}$ \\
\hline MS (control) & $0.0 \pm 0.0$ & $\mathrm{c}$ & $0.0 \pm 0.0$ & $\mathrm{~b}$ \\
MS+HC & $66.6 \pm 27.2$ & $\mathrm{a}$ & $33.3 \pm 0.0$ & $\mathrm{a}$ \\
$\mathrm{MS}+\mathrm{HC}+\mathrm{KIN}$ & $0.46 \mu \mathrm{M}$ & $25.0 \pm 31.9$ & $\mathrm{~b}$ & $8.3 \pm 16.6$ & $\mathrm{~b}$ \\
$\mathrm{MS}+\mathrm{HC}+\mathrm{KIN} 4,65 \mu \mathrm{M}$ & $16.6 \pm 19.2$ & $\mathrm{~b}$ & $0.0 \pm 0.0$ & $\mathrm{~b}$ \\
$\mathrm{MS}+\mathrm{HC}+\mathrm{AC}$ & $0.0 \pm 0.0$ & $\mathrm{c}$ & $0.0 \pm 0.0$ & $\mathrm{~b}$ \\
$\mathrm{MS}+\mathrm{HC}+\mathrm{KIN} 0.46 \mu \mathrm{M}+\mathrm{AC}$ & $8.3 \pm 16.6$ & $\mathrm{c}$ & $0.0 \pm 0.0$ & $\mathrm{~b}$ \\
$\mathrm{MS}+\mathrm{HC}+\mathrm{KIN} 4.65 \mu \mathrm{M}+\mathrm{AC}$ & $8.3 \pm 16.6$ & $\mathrm{c}$ & $0.0 \pm 0.0$ & $\mathrm{~b}$ \\
\hline
\end{tabular}

**Means \pm s.e (standard error) of 5 replicates with 4 explants. Means followed by the same letter within the same column are not statistically significant by Tukey test $(\mathrm{p} \leq 0.05)$ (**Médias \pm desvio padrão de 5 repetições de 4 explantes. Médias seguidas da mesma letra, na coluna, não diferem pelo teste de Tukey $(\mathrm{p} \leq 0,05)$. 


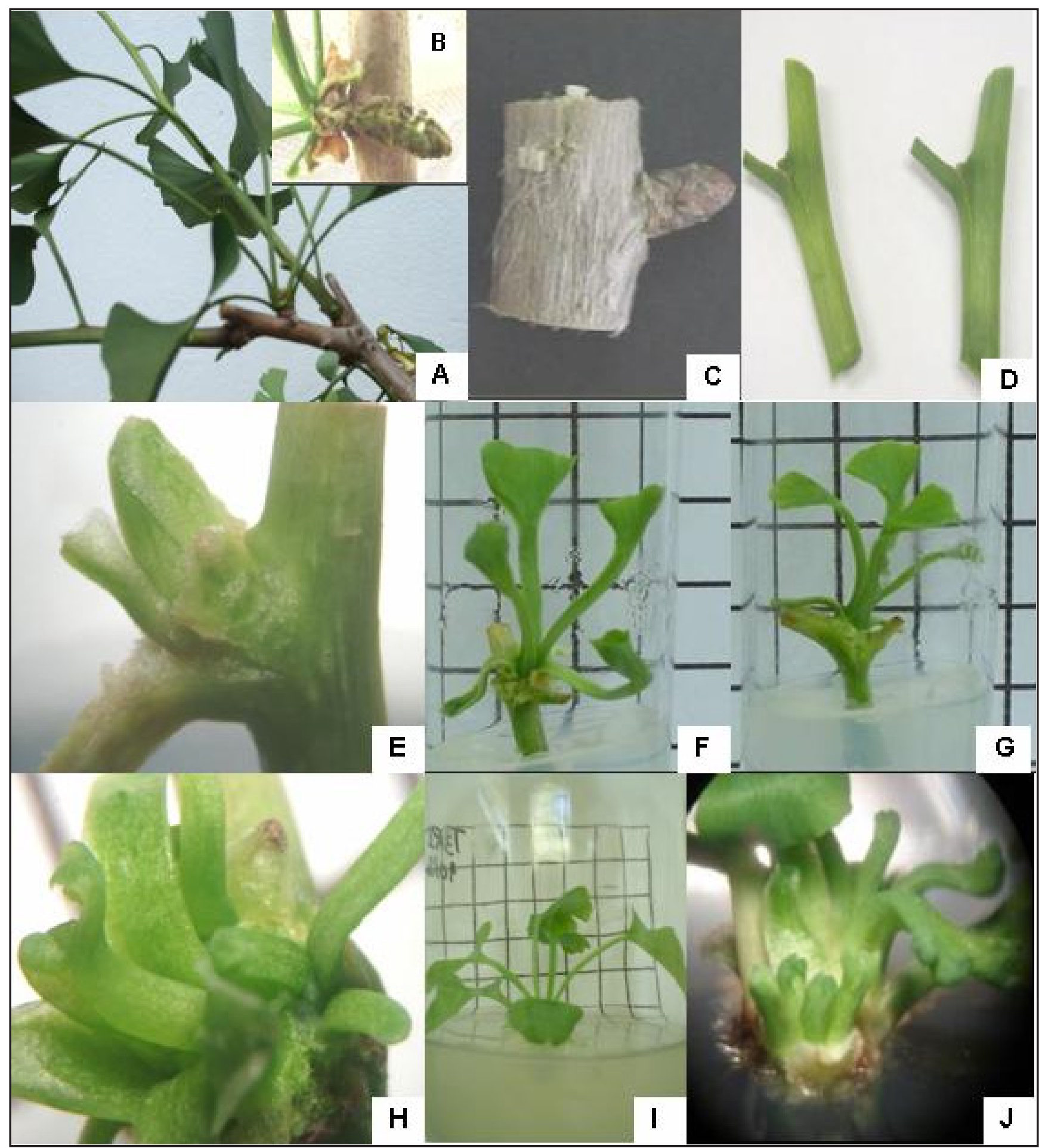

Figure 1. Adult plants of Ginkgo biloba grown in the greenhouse and in vitro. (A) Ginkgo plants donor of explants showing short and long shoots, formed during the growth season; (B) Microsporangiate strobili; (C) Nodal segments of woody branches; (D) Nodal segments of herbaceous branches; (E) In vitro shoot induction and multiplication from axillary buds of herbaceous nodal segment cultivated on MS medium supplemented with hydrolyzed casein $500 \mathrm{mg} \mathrm{L}^{-1}$ at 15 days; (F) short shoots, at 30 days of cultivation; (G) long shoots at 30 days of cultivation; (H) multiple shoots in nodal segment; (I) isolated shoot by nodal segment and in the multiplication process; and (J) multiple shoots differentiated in nodal segment [plantas-matrizes adultas de Ginkgo biloba cultivadas em casa de vegetação e in vitro: (A) plantas matrizes exibindo brotos curtos e longos, emitidos durante a estação de crescimento; (B) estruturas portadoras de microesporângios; (C) segmento nodal lenhoso (D) segmentos nodais herbáceos; (E) indução e multiplicação in vitro de brotos formados a partir de gemas axilares em segmentos nodais herbáceos, cultivados em meio de cultura MS suplementado com $500 \mathrm{mg} \mathrm{L}^{-1}$ de caseína hidrolisada, aos 15 dias; (F) brotos curtos, aos 30 dias de cultivo; (G) brotos longos, aos 30 dias de cultivo; (H) múltiplos brotos em segmento nodal; (I) broto isolado do segmento nodal e em fase de multiplicação e (J) com múltiplos brotos]. Passo Fundo, UPF, 2009. 
medium. In the control, MS basal salt medium, $80 \%$ of nodal segments showed swollen axillary buds (data not shown) however, it was not able to induce shoots formation (Table 1).

The HC was essential for the development of axillary buds and to the formation of multiple shoots in nodal segments of ginkgo. The best results were obtained in MS medium containing HC $500 \mathrm{mg} \mathrm{L}^{-1}$, where $85 \%$ of nodal segments developed shoots from axillary buds, and 35\% formed multiple shoots (Table 1). In this treatment, at 15 days of culture, we observed the axillary buds of nodal segments partially surrounded by bracts (Figure 1E) and at 30 days, the shoots and the first normal leaf became evident (Figure 1F, G). After 30 days of cultivation multiple shoots were observed in nodal segments in this same medium (Figure 1H).

The KIN, at concentration of 0.46 $\mu \mathrm{M}$ and $4.65 \mu \mathrm{M}$, when added to the culture medium containing $\mathrm{HC}$, caused a reduction in the percentage of shoots induction, when compared to the treatment with only HC. The same behavior was observed on the induction of multiple shoots (Table 1).

The AC was not effective on induction of shoots or multiple shoots in ginkgo, causing an inhibitory effect on the organogenic process. However, its negative effect of AC was less pronounced allowing the axillary shoot development in nodal segments, when combined with KIN $0.46 \mu \mathrm{M}$ or 4.65 $\mu \mathrm{M}$ and multiple shoots when combined with KIN 4.65 $\mu \mathrm{M}$ (Table 1).

Shoot multiplication - Similar behavior observed during the establishment stage was also observed during the shoots multiplication stage. The best results were obtained in MS medium containing $\mathrm{HC} 500 \mathrm{mg} \mathrm{L}^{-1}$. In this treatment, $66.6 \%$ of pre-existing shoots produced new shoots and $33.3 \%$ gave rise to multiple shoots induction (Table 2, Figure 1I, J).

The HC was essential for the development of Ginkgo biloba axillary buds as well as to the multiple shoots formation at the establishment and multiplication stages (Tables 1 and 2). This positive effect of $\mathrm{HC}$ was also observed in the development of axillary buds from nodal segments of ginkgo seedlings germinated in vitro (Hao et al., 2000). These authors observed that the multiplication rate was $4: 1$ when the explants were cultured on MS basal medium supplemented with HC $500 \mathrm{mg} \mathrm{L}^{-1}$, compared to the multiplication rate $1: 1$ observed in the control treatment. The HC is an organic nitrogen source that provides a set of amino acids that stimulate the growth of many cultures in vitro (Caldas et al., 1998).

Complex mixtures such as extracts of seeds and fruits, coconut water, hydrolyzed casein, for instance, are often added to media to stimulate the growth of in vitro cultures. Extract of endosperm of mature seeds of ginkgo, added to the MS culture medium was essential for the induction of shoots in nodal segments of seedlings and in apical buds of ginkgo (Tommazi \& Scaramuzzi, 2004).

The effects of KIN and the AC, observed at the establishment, were also observed in the shoots multiplication stage. There was a reduction in the frequency of formation of shoots in the presence of these substances compared to the treatment containing only $\mathrm{HC}$ (Table 2). The negative effects of KIN and $\mathrm{AC}$ were intensified over three subcultures in the presence of these substances (data not shown). These effects were expressed in shoots with the production of leaves with atypical forms and vitreous appearance, showing symptoms of hyperhydricity, as well as less developed when compared to shoots formed and cultivated in the presence of $\mathrm{HC}$ isolated.

The assessment of the effects of different cytokinins on shoot multiplication of ginkgo, on MS basal medium, showed that KIN promoted the formation of multiple shoots in $41 \%$ of propagules, while the BAP (6-benzylaminopurine) and the TDZ (thidiazuron), at the same concentration (1.0 $\left.\mathrm{mg} \mathrm{L}^{-1} ; 4.54 \mu \mathrm{M}\right)$, led to the formation of calluses and death of propagules with all cytokinins tested, after successive subcultures, caused negative effects on development and quality of sprouts (Mantovani, 2007).

Plant growth regulators NAA and
ZEA, and adenine, when added to the MS culture medium, also inhibited the development of shoots and resulted in the callus formation in axillary buds and nodal segments of ginkgo seedlings (Hao et al., 2000).

The AC has properties of adsorption of toxic substances of the culture medium and reduction of light incidence on the base of the explants (Bonga, 1985). The AC usually causes positive effects on multiplication, elongation and in the shoots rooting of Didymopanax morototoni and Cordia trichotoma (Mantovani et al., 1999, 2001). In Ginkgo biloba the AC added to the culture medium induced higher regenerative ability of nodal segments from in vitro germinated seedlings ( $\mathrm{Hu}$ et al., 2002). In our experiment however, the AC caused inhibitory effects on the formation and multiplication of shoots.

In this work we observed two distinct patterns of in vitro development of axillary buds in nodal segments of herbaceous branches of $G$. biloba during the establishment stage: 1) short shoots with very close internodes (crowded internodes), slow and limited growth and expansion of only a few leaves (about 4 or 5), not found any apical elongation during the establishment stage (Figure 1F); 2) long shoots with separated nodes and leaves in spiral phyllotaxy (Figure 1G). These shoots had higher elongation, both at the establishment and multiplication stages.

It was not possible to establish a relationship between the development patterns in vitro of the shoots with the position occupied by the nodal segment in the original branch in donor plants. Nodal segments, taken from the same branch, developed long shoots while others developed short shoots, regardless of position proximal or distal in the branch of origin.

During the development of the branches in the donor plants of ginkgo, we found that short and long shoots arise from the development of axillary buds on the same branch. The short shoots may maintain a slow pattern of growth, with annual growth of some leaves, for many years. This pattern, however, is reversible, since a short shoot may suddenly develop a long one and, 
moreover, the apical growth of a long shoot can be delayed by several seasons, simulating the growth pattern of a short lateral shoot (Gifford \& Foster, 1989).

This behavior of the irregular pattern of branching defines the architecture of the crown ginkgo tree. The dimorphism of shoots, observed in plants is a natural behavior of the species and may explain the irregularity of the responses observed in vitro, as axillary buds that do not develop, shoots that elongate and others that remain in rosettes form.

The high regenerative capacity of the herbaceous nodal segments, obtained from adult plants, indicates that these explants can be used to establish an in vitro propagation system for G. biloba.

The hydrolyzed casein induces the formation of axillary buds and multiple shoots in nodal segments in the establishment and the multiplication stages, while the activated charcoal and kinetin cause inhibitory effects in this process.

Short and long shoots characterize the pattern of development of axillary buds in nodal segments of ginkgo grown in vitro, similar to what occurs in vivo.

Our results indicate the viability of using explants obtained from adult plants of ginkgo for the in vitro propagation of this species, especially in places where obtaining embryonic explants becomes difficult. Thus, also envisages the possibility of using this regeneration system for studies in genetic transformation of this species. Further studies should focus on optimizing every stage of the in vitro propagation.

\section{ACKNOWLEDGEMENTS}

The first author thanks to CAPES for the scholarship awarded.

\section{REFERENCES}

BALZ JP; COURTOIS D; DRIEU J; DRIEU
K; REYNOIRD JP; SOHIER C; TENG BP; TOUCHÉ A; PÉTIARD V. 1999. Production of Ginkgolides and Bilobalide by Ginkgo biloba plants and tissue cultures. Planta Medica 65: 620-626.

BONGA JM. 1985. Tissue culture techniques. In: BONGA JM, DURZAN DJ (eds). Tissue culture in forestry. Dordrecht: Martinus Nijhoff. p 4-35.

BRENNER ED; KATARI MS; STEVENSON DW; RUDD SS; DOUGLAS AW; MOSS WN; TWIGG RW; RUNKO S; STELLARI GM; McCOMBIE WR; CORUZZI GM. 2005. EST analysis in Ginkgo biloba: an assessment of conserved developmental regulators and gymnosperm specific genes. BMC Genomics 6: 143.

CALDAS LS; HARIDASAN P; FERREIRA ME. 1998. Meios nutritivos. In: TORRES AC; CALDAS LS; BUSO JA (eds). Cultura de tecidos e transformação genética de plantas. Brasília: EMBRAPA - SPI/ CNPH. p 87-132.

CAMPER ND; COKER PS; WEDGE DE; KEESE RJ. 1997. In vitro culture of Ginkgo. In Vitro Cellular and Developmental Biology Plant 33: 125-127.

CARRIER DJ; CHAURET N; MANCINI M; COULOMBE P; NEUFELD R; WEBWER M, ARCHAMBAULT J. 1991. Detection of ginkgolide A in G. biloba cell cultures. Plant Cell Reports 10: 256-259.

CHENG SY; XU F; WANG Y. 2009. Advances in the study of flavonoids in Ginkgo biloba leaves. Journal of Medicinal Plants Research 3: 1248-1252.

CHOI PS; CHO DY; SOH WY. 2004. Shoot organogenesis from immature zygotic embryo cultures of Ginkgo biloba. Biologia Plantarum 47: 309-312.

GIFFORD EM; FOSTER AS. 1989. Morphology and evolution of vascular plants. New York: WH Freeman and Company. 626p.

GRAY DE; UPTON R; CHANDRA A; PORTER A; HARRIS RK. 2006. Quantitative analysis of flavonol glycosides in Ginkgo biloba: a comparison of two analytical methods. Phytochemical Analysis 17: 56-62.

HAO G; DU X; YOU Y; HOU F; FAN Z; ZHANG H. 2000. Effects of various factors on the growth and development of cultured axillary buds of Ginkgo biloba in vitro. Forest Research 13: 217-221.

HAO G; DU X; ZHAO F; SHI R; WANG J. 2009. Role of nitric oxide in UV-B-induced activation of PAL and stimulation of flavonoid biosynthesis in Ginkgo biloba callus. Cell Tissue and Organ Culture 97: 175-185.

HU H; YANG J; YANG D; WANG Y. 2002. Study on stem section culture conditions in vitro in Ginkgo biloba. Scientia Silvae Sinicae 38: 52-56.
KANG SM; MIN JY; KIM YD; KANG YM; PARK DJ; JUNG HN; KIM SW; CHOI MS. 2006. Effects of methyl jasmonate and salicylic acid on the production of bilobalide and ginkgolides in cell cultures of Ginkgo biloba. In Vitro Cellular and Developmental Biology 42: 44-49.

L A URAIN D; CHÉNIEUX JC; TRÉMOUILLAUX-GUILLER J. 1996. Somatic embryogenesis from immature zygotic embryos of Ginkgo biloba. Plant Cells, Tissue and Organ Culture 44: 19-24.

MANTOVANI NC; FRANCO ETH; GUERRA MP. 1999. Micropropagação de caixeta Didymopanax morototoni (Aubl) Dcne et Planch. Ciência Florestal 9: 47-61.

MANTOVANI NC; FRANCO ETH; VESTENA S. 2001. Regeneração in vitro de Louro-Pardo (Cordia trichotoma (Vellozo) Arrabida ex Steudel). Ciência Florestal 11: 93-101.

MANTOVANI NC. 2007. Propagação vegetativa e cultivo in vitro de Bixa orellana L. e Ginkgo biloba L. Viçosa: UFV. 135p. (Tese doutorado).

MONTEZ-LÓPEZ JJ; RODRÍGUEZ JLLO. 2001. In vitro establishment and sprouting of axillary buds and shoot apex of ginkgo (Ginkgo biloba L.). Revista Chapingo Serie Horticultura 7: 49-59.

MURASHIGE T; SKOOG F. 1962. A revised medium for rapid growth and bioassays with tobacco tissue cultures. Physiologia Plantarum 15: 473-497.

RIBEIRO JÚNIOR JI, 2001. Análises estatísticas no SAEG. Viçosa: UFV, 301p.

SEXTO PAS. 2005. Cultivo in vitro e estaquia de Ginkgo biloba L. Passo Fundo: UPF. $179 f$ (Dissertação mestrado).

SOHIER C; COURTOIS D. 2007. Ginkgo biloba and production of secondary metabolites. In: KAYSER O; QUAX WJ (eds). Medicinal plant biotechnology: from basic research to industrial applications. Weinheim: WileyVCH Verlag GmbH \& Co. p 493-514.

TOMMASI F; SCARAMUZZI F. 2004. In vitro propagation of Ginkgo biloba by using various bud cultures. Biologia Plantarum 48: 297-300.

VAN BEEK TA. 2002. Chemical analysis of Ginkgo biloba leaves and extracts. Journal of Chromatography. 937: 21-55.

WEIMANN S; ROLL S; SCHWARZBACH C; VAUTH C; WILLICH SN. 2010. Effects of Ginkgo biloba in dementia: systematic review and meta-analysis. BMC Geriatrics. 10: 1-14

ZHOU, L; MENG, Q; QUIAN, T; YANG, Z. 2011. Ginkgo biloba extract enhances glucose tolerance in hyperinsulinism-induced hepatic cells. Journal of Natural Medicines 65: 50-56. 